\title{
On the Occurrence of Binucleate and Multinucleate Cells in Growing Tissues.
}

\author{
BY \\ RUDOLF BEER \\ AND \\ AGNES ARBER.
}

\begin{abstract}
A CONSIDERABLE literature exists concerning multinucleate cells in the higher plants, tending to show that such cells are far from rare. For some time we have been making a study of the subject, at first independently and more recently conjointly. Our observations have led us to the conclusion that, in the case of the cortical and medullary parenchyma of stems, a stage in which each cell characteristically contains more than one nucleus often intervenes as a normal phase of development between the meristematic and mature conditions. This stage may be highly protracted, or it may be so brief that it is easily overlooked. It is most usual to find two nuclei, but the number may be much higher in certain species. We have not yet satisfied ourselves as to the fate of these nuclei, but there are indications that, at, least in some cases, fusions occur at a later stage.

Our present observations would not justify us in saying that the binucleate or multinucleate phase is universal, but we have found it so widely that we should not be surprised if it eventually proved to be the rule rather than the exception. Our preliminary investigation has established the existence of a binucleate or multinucleate phase, of greater or less completeness, in the stem organs of fifty species of Dicotyledons belonging to twenty-seven natural orders and of seventeen species of Monocotyledons belonging to four orders. These cases range from trees to small annual herbs and include examples both of vegetative and reproductive axes. We have at present given most of our attention to stems, but we have also noticed multinucleate cells in the leaf-sheaths of seven species of Gramineae ${ }^{1}$ and one species of Araceae, and binucleate cells in the

1 Multinucleate cells in the stems and leaf-gheaths of grasses were recorded by one of us in 1899. Beer, R. : On the Multinuclear Cells of some Grasses. Natural Science, vol. Xv, pp. 134-9, $2 \mathrm{pl}, 1899$.
\end{abstract}

[Annals of Botany, Vol. XXIX. No. CXV1. October, 1915-) 


\section{Beer and Arber.-Binucleate and Multinucleate Cells.}

cotyledons of four species of Liliaceae and in the roots of Bambusa, sp., Anthurium violaceum, and Stratiotes aloides. ${ }^{1}$ Our thanks are due to Miss Ethel Sargant, who has allowed us to examine in this connexion certain of her preparations of Liliaceae seedlings. We have made few observations outside the Angiosperms, but we have found a binucleate stage in the stems of Araucaria imbricata and of Equisetum maximum and $E$. limosum, showing that this phase is not confined to the highest groups. Taking all the cases together and including stems and leaves, we have found the binucleate or multinucleate phase in seventy-six species belonging to thirty-three orders.

The nuclei of the multinucleate cells generally arise by mitosis, but there are certain exceptional features connected with this mitosis and with the behaviour of the associated cytoplasm. The most striking of these is that two daughter-nuclei in the telophase, between which no wallformation is in progress, are often found enclosed in a hollow sphere of dense and deeply-staining protoplasm, the appearance at first glance suggesting a cell within a cell. We have observed this singular phenomenon in thirty-five species, representing seventeen natural orders. These and other matters arising out of our observations we hope to discuss in a future paper, but as the subject is a wide one and will take considerable time to work out in detail, we wish to put-on record this preliminary survey of our results.

The expenses of our work are being partially borne by a grant from the Newnham College Fellowship Committee, for which we desire to tender our thanks. We also wish to express our indebtedness to Prof. W. Bateson, F.R.S., for his kind permission to grow and collect material at the John Innes Horticultural Institution, and to Mr. R. I. Lynch, M.A., Curator of the Cambridge Botanic Garden, and Mr. E. J. Allard for valuable help in the same connexion.

1 The binacleate cells in the roots of Stratiotes and Anthurium appear to differ from the other cases recorded in this note in that the plarality of nuclei here arises through a form of amitosis. See Arber, A. : On Root Development in Stratiotes aloides, L., with special reference to the occurrence of Amitosis in an embryonic tissue. Proc. Camb. Phil. Soc., vol. xrii, pp. 369-79, 2 pl., 1914. 